\title{
Influence of two choline-based ionic liquids on the solubility of caffeine
}

\section{Influência de dois líquidos iónicos derivados de colina na solubilidade da cafeína}

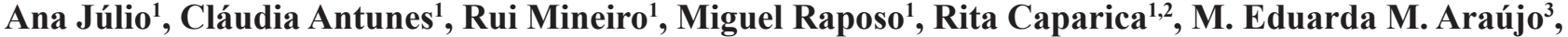 \\ Catarina Rosado', Pedro Fonte ${ }^{1,4}$, Tânia Santos de Almeida ${ }^{1}$ \\ ${ }^{1}$ CBIOS-Research Center for Biosciences and Health Technologies, Lusófona University, Lisbon, Portugal. \\ ${ }^{2}$ Department of Biomedical Sciences, University of Alcalá, Ctra. Madrid-Barcelona Km. 33.600, 28871 Alcalá de Henares, \\ Madrid, Spain. \\ ${ }^{3}$ Centro de Química e Bioquímica, Faculdade de Ciências, Universidade de Lisboa, 1749-016 Lisboa, Portugal. \\ ${ }^{4}$ UCIBIO, REQUIMTE, Department of Chemical Sciences - Applied Chemistry Lab, Faculty of Pharmacy, University of \\ Porto, Porto, Portugal. \\ Email: ana.julio@ulusofona.pt
}

\begin{abstract}
Poor drug solubility represents a major problem for the development of new drug delivery systems. Finding new excipients that promote drug solubility is one of the strategies currently used. In this context, ionic liquids (ILs) have been studied as solubility promoters due to their ability to be placed in either lipophilic or hydrophilic solutions.

Two choline-based ILs, [Cho][Met] and [Cho][Cys], were prepared and their influence on the solubility of a model hydrophilic drug, caffeine, was evaluated at $25^{\circ} \mathrm{C}$.

Results show that both ILs improved drug solubility, with [Cho][Met] providing a higher soluble concentration. Our results suggest that the studied choline-based ILs are effective solubility enhancers of caffeine and thus may potentially be used as functional ingredients in drug delivery systems.
\end{abstract}

Keywords: Choline-based Ionic Liquids, Caffeine, Poorly soluble drugs, Solubility enhancement.

\section{Resumo}

A baixa solubilidade de ativos representa um grande problema para o desenvolvimento de novos sistemas de administração de fármacos. Desta forma, encontrar novos excipientes que promovem a solubilidade do fármaco é uma das estratégias utilizadas atualmente. Neste contexto, os líquidos iónicos (LI) têm sido estudados como promotores de solubilidade, devido à sua capacidade de serem colocados em soluções lipofílicas ou hidrofílicas. Neste âmbito, foram preparados dois LI derivados de colina, [Cho][Met] e [Cho][Cys], e a sua influência na solubilidade de um fármaco modelo hidrofílico, cafeína, foi avaliada a $25^{\circ} \mathrm{C}$.

Os resultados mostram que ambos os LI melhoraram a solubilidade do fármaco, com o LI [Cho][Met] a permitir um maior aumento da solubilidade.

Os nossos resultados sugerem que os LI derivados da colina estudados são eficazes como promotores de solubilidade da cafeína e, portanto, podem potencialmente ser usados como ingredientes funcionais em sistemas de libertação de fármacos.

Palavras-Chave: Líquidos iónicos de colina, Cafeína, Ativos pouco solúveis, Aumento de Solubilidade. 


\section{Introduction}

The physiological accessibility of a drug generally requires its dissolution. Thus, the low solubility and/or permeation of some drugs are major challenges for the pharmaceutical and cosmetic industries. This problem results in lower therapeutic efficiency and bioavailability, which may lead to the need to incorporate higher drug doses to reach the therapeutic dose [1]. To overcome these weaknesses, it is important to develop new and/or more efficient drug delivery systems and to find new functional ingredients that may increase drug solubility and/or loading and stability.

In this context, ionic liquids (ILs) may represent an alternative to enhance solubility due to their unique characteristics which arise from their particular structures. ILs are salts, composed of an organic cation and an organic or inorganic anion. They have melting points below $100{ }^{\circ} \mathrm{C}$ and some are liquid at room temperature [1-6]"ISBN" : "1520-6890 (Electronic. Due to these characteristics, ILs are currently used in pharmaceutical sciences, since they may be tailored to achieve the physicochemical desired properties. These properties include high thermal and chemical stability, low vapour pressure, nonflammability, negligible volatility and reusability [7-10]. As a consequence of these properties, these salts have been used in the pharmaceutical industry with several purposes, such as extractants of pharmaceutical compounds from aqueous solutions [13-15] sediments and effluents. A completely biocompatible aqueous biphasic system composed of Tween 20 or Tween 80 and the ionic liquid choline chloride has been designed for extracting non-steroidal anti-inflammatory drugs from aqueous streams. After an initial evaluation of the salting out potential of the selected ionic liquid at different temperatures, the extraction capacity of these systems to be applied for ibuprofen and diclofenac removal from aqueous streams was assessed. Very high levels of contaminant removal (higher than $90 \%$, as solubility enhancers $[14,16]$, as solvents and catalysts of active pharmaceutical ingredients [14,17]ionic liquids (ILs, as oil or water substitutes, and as additives or as surfactants in emulsions and micro emulsions [18-22] ionic liqs. (ILs. Also, their structural tailoring may allow them to be placed in aqueous, oily or hydroalcoholic solutions[11,12]. This last characteristic is crucial when considering their use as excipients in many drug delivery systems [8].

ILs have been classified in three generations, according their structure and chemical properties $[1,8,23,24]$. The first generation includes dialkylimidazolium and alkylpyridinium cations. The second generation is com-

\section{Introdução}

A acessibilidade fisiológica de um medicamento geralmente requer a sua dissolução. Assim, a baixa solubilidade e/ou permeação de alguns fármacos são grandes desafios para as indústrias farmacêutica e cosmética. Esta problemática resulta em menor eficiência terapêutica e biodisponibilidade, o que pode levar à necessidade de incorporar maiores doses de fármaco para atingir a dose terapêutica [1]. Desta forma, para superar essas fraquezas, é importante desenvolver novos e/ou mais eficientes sistemas de veiculação de fármacos e encontrar novos ingredientes funcionais que possam aumentar a solubilidade do fármaco e/ou a incorporação e estabilidade.

Neste contexto, os líquidos iónicos (LI) podem representar uma alternativa para aumentar a solubilidade, devido às suas características únicas, que surgem das suas estruturas particulares. Os LI são sais, um catião orgânico e um anião orgânico ou inorgânico, que têm pontos de fusão abaixo de $100{ }^{\circ} \mathrm{C}$ e, alguns deles, são líquidos à temperatura ambiente [1-6]"ISBN" : “15206890 (Electronic. Devido a estas características, os LI são, atualmente, utilizados em Ciências Farmacêuticas, uma vez que podem ser modificados para atingir as propriedades físico-químicas necessárias. Algumas dessas propriedades são elevada estabilidade térmica e química, baixa pressão de vapor, não são inflamáveis, volatilidade e reutilização insignificantes [7-10]. Como consequência das propriedades mencionadas anteriormente, esses sais têm sido utilizados na área farmacêutica com vários objetivos, como extratores de compostos farmacêuticos de soluções aquosas [13-15]sediments and effluents. A completely biocompatible aqueous biphasic system composed of Tween 20 or Tween 80 and the ionic liquid choline chloride has been designed for extracting non-steroidal anti-inflammatory drugs from aqueous streams. After an initial evaluation of the salting out potential of the selected ionic liquid at different temperatures, the extraction capacity of these systems to be applied for ibuprofen and diclofenac removal from aqueous streams was assessed. Very high levels of contaminant removal (higher than $90 \%$, como promotores de solubilidade $[14,16]$, como solventes e catalisadores de ingredientes farmacêuticos ativos [14,17] ionic liquids (ILs e como substitutos de óleo ou água, como aditivos ou como surfactantes em emulsões e micro emulsões [18-22]ionic liqs. (ILs. Além disso, a sua modificação estrutural pode permitir que estes sejam colocados em soluções aquosas, oleosas ou hidroalcoólicas $[11,12]$. Esta última característica é crucial quando se considera o seu uso como excipiente em 
posed of dialkylimidazolium, alkylpyridinium, ammonium and phosphonium cations. The last generation includes biodegradable and natural ions and ions with known biological activities, and within this category choline-based ILs are among the most common ILs of this generation $[1,23]$. Hence, this last generation of ILs has several interesting characteristics, particularly the choline-based ILs due to their lower toxicity, that increase their potential to be used in the pharmaceutics, ecology, and/or biology fields.

With this in mind, the aim of this work was to synthesize two choline-based ILs and investigate their influence on the solubility of a model hydrophilic drug, caffeine, at room temperature $\left(25 \pm 2{ }^{\circ} \mathrm{C}\right)$.

\section{Material and Methods}

\section{Materials and Reagents}

All reagents and solvents used for the IL synthesis were of analytical purity and provided by Sigma-Aldrich. Anhydrous caffeine was purchased from Fagron, Barcelona, Spain. Deionized water was used for all experiments.

\section{Methods}

\section{Synthesis of ILs}

The choline-based ionic liquids (2-hydroxyethyl)trimethylammonium methionate, [Cho][Met] and (2-hydroxyethyl)-trimethylammonium ((R,R)-3,3'ditiobis(2-aminopropanoate), [Cho][Cys] were prepared according to the procedures described in the literature [16].

\section{Solubility studies}

Over-saturated solutions of caffeine were prepared using $3 \mathrm{~mL}$ deionized water or a mixture of deionized water:IL 99.8:0.2 and placed in a horizontal shaker (IKA VIBRAX VXR ${ }^{\circledR}$, from LTF Labortechnik GmbH $\&$ Co, Bodensee, Germany) at $100 \mathrm{rpm}$ at $25 \pm 2{ }^{\circ} \mathrm{C}$ over 72 hours. All samples were prepared in triplicate. After 72 hours, they were withdrawn, filtered, diluted and analysed by UV-Vis spectrophotometry (Evolution 600, Thermo Scientific, Waltham, MA, USA) at the maximum absorption wavelength of the drug $(273 \mathrm{~nm})$. vários sistemas de veiculação de fármacos [8].

Os LI têm sido classificados em três gerações, de acordo com as suas estrutura e propriedades químicas $[1,8,23,24]$. Na primeira geração estão incluídos os catiões dialquilimidazólio e alquilpiridínio, sendo que a segunda geração é composta pelos catiões dialquilimidazólio, alquilpiridínio, amónio e fosfónio. A última geração inclui iões naturais e biodegradáveis ou iões com atividades biológicas conhecidas e, nesta categoria, os LI à base de colina estão entre os LI mais comuns desta geração $[1,23]$. Assim, esta última geração de LI tem várias características interessantes, particularmente os LI à base de colina, devido à sua menor toxicidade, que aumentam seu potencial para serem usados nas áreas farmacêutica, ecológica e/ou biológica.

Com tudo isso em mente, o objetivo deste trabalho foi sintetizar dois LI derivados da colina e investigar a sua influência na solubilidade de um fármaco modelo hidrofílico- cafeína- à temperatura ambiente $\left(25 \pm 2{ }^{\circ} \mathrm{C}\right)$.

\section{Material e Métodos}

\section{Materiais e Reagentes}

Todos os reagentes e solventes utilizados para a síntese de IL são de pureza analítica e fornecidos pela Sigma-Aldrich. Em relação aos fármacos, a cafeína anidra foi adquirida pela Fagron, Barcelona, Espanha. Água desionizada foi usada para todos os ensaios.

\section{Métodos}

\section{Sintese de ILs}

Os líquidos iónicos à base de colina (2-hidroxietil)-trimetilamónio metionato, [Cho][Met], e (2-hidroxietil)-trimetilamónio ((R, R)-3,3'-ditiobis(2-aminopropanoato), [Cho][ Cys], foram preparados de acordo com os procedimentos descritos na literatura [16].

\section{Estudos de solubilidade}

Foram preparadas soluções sobressaturadas de cafeína em $3 \mathrm{~mL}$ de água deionizada ou uma mistura de água desionizada:LI 99,8:0,2 e colocada em um agitador horizontal (IKA VIBRAX VXR®, da LTF Labortechnik $\mathrm{GmbH} \& \mathrm{Co}$, Bodensee, Alemanha) a $100 \mathrm{rpm}$, a $25 \pm$ $2{ }^{\circ} \mathrm{C}$ durante 72 horas. Todas as amostras foram realizadas em triplicado. Após esse período foram retiradas, filtradas, diluídas e analisadas por espectrofotometria UV-Vis (Evolution 600, Thermo Scientific, Waltham, MA, EUA) no comprimento de onda de máxima absorção de cada fármaco $(273 \mathrm{~nm})$. A curva de calibração 
The calibration curve for caffeine was prepared over a concentration range from 2 to $20 \mu \mathrm{g} / \mathrm{mL}$, using water as solvent.

\section{Statistical Analysis}

Differences in mean values for drug solubility, as determined by UV-Vis, were evaluated by one-way analysis of variance, ANOVA, followed by Tukey's multiple comparison test. The values are expressed as mean \pm standard deviation, SD. The differences between individual means were significant at $p<0.05$ level. The data was treated using GraphPad Prism $5^{\circledR}$ from GraphPad Software (San Diego, CA, USA).

\section{Results and Discussion}

Two choline-based ILs, (2-hydroxyethyl)-trimethylammonium methionate [Cho][Met] and (2-hydroxyethyl)trimethylammonium ((R,R)-3,3'-ditiobis(2-aminopropanoate) [Cho][Cys], were prepared with $87 \%$ and 36 $\%$ yield, respectively, according to the procedure described in the literature [16]. The [Cho][Met] showed a light-yellow colour, while [Cho][Cys] presented with a dark yellow colour, in agreement with previously reported results [12]. Both were liquid at room temperature, a very relevant feature when considering their use as pharmaceutical excipients in drug delivery systems. The ${ }^{1} \mathrm{H}-\mathrm{NMR}$ spectroscopic data of the synthetized IL agreed with previously described data $[11,12]$ (data not shown).

Herein, caffeine was used as active model and water used as the primary solvent. Due to its low cost, biocompatiblity, and availablity, water is one of the most advantageous solvents in both pharmaceutical and cosmetic delivery systems. The influence of the prepared ILs on the solubility of caffeine in water and water:IL (99.8:0.2, w/w) mixtures was determined at $25^{\circ} \mathrm{C}$ (Figure 1). The percentage of IL $(0.2 \%)$ used was the maximum safe concentration, accordingly to toxicity results previously obtained by our group [16]. The solubility of caffeine in deionized water was $20.02 \pm 0.06 \mathrm{mg} / \mathrm{mL}$, which is in agreement with the literature $(20.00 \pm 0.08$ $\mathrm{mg} / \mathrm{mL}$ ) [25].

Results show that in the presence of both ILs, the solubility of caffeine is higher $(22.21 \pm 0.91 \mathrm{mg} / \mathrm{mL}$ with [Cho][Cys] and $24.74 \pm 1.01 \mathrm{mg} / \mathrm{mL}$ with [Cho][Met]), when compared with its solubility in water (Figure 1). Furthermore, results also demonstrate that [Cho][Met] is a better solubility promotor than [Cho][Cys], with statistically significant differences $(\mathrm{p}<0.001)$.

It is also quite relevant to acknowledge that even though both ILs allow a significant improvement in solubility, para a cafeina foi preparada no intervalo de concentrações entre 2 e $20 \mu \mathrm{g} / \mathrm{mL}$, usando água como solvente.

\section{Análise Estatística}

As diferenças nos valores médios para a solubilidade do ativo, determinada por UV-Vis, foram avaliadas por análise de variância one-way, ANOVA, seguida pelo teste de comparação múltipla de Tukey. Os valores são expressos como média \pm desvio padrão, DP. As diferenças entre as médias individuais foram significativas ao nível de $\mathrm{p}<0,05$. Os dados foram tratados usando o GraphPad Prism 5® da GraphPad Software (San Diego, CA, EUA).

\section{Resultados e Discussão}

Dois LI derivados de colina, [Cho][Met] e [Cho][Cys], foram preparados com $87 \%$ e $36 \%$ de rendimento, respetivamente, de acordo com o procedimento descrito na literatura [16]. O [Cho][Met] mostrou uma cor amarela clara enquanto o [Cho][Cys] apresentou um amarelo escuro, ambos apresentaram-se na forma líquida à temperatura ambiente, o que está de acordo com os resultados relatados anteriormente [12]. Esta última característica é muito relevante quando se considera seu uso como excipientes farmacêuticos em sistemas de veiculação de fármacos. Os dados espectroscópicos de ${ }^{1} \mathrm{H}-\mathrm{RMN}$ do LI sintetizado concordaram com dados previamente descritos [11,12]

Neste trabalho, a cafeína foi utilizada como ativo modelo e como a água é um dos solventes mais vantajosos em sistemas de veiculação farmacêuticos e cosméticos, por ser barato, biocompatível e acessível, a influência dos LI preparados na solubilidade da cafeína em água e água:IL $(99,8: 0,2, \mathrm{~m} / \mathrm{m})$ as misturas foram realizadas a $25^{\circ} \mathrm{C}$ (Figura 1). A percentagem de LI usada $(0.2 \%)$ é a máxima possível de acordo com os resultados de estudos de toxicidade anteriormente realizados pelo nosso grupo [16]. Além disso, a solubilidade da cafeína em água desionizada foi de $20,02 \pm 0,06 \mathrm{mg} / \mathrm{mL}$, o que está de acordo com a literatura $(20,00 \pm 0,08 \mathrm{mg} / \mathrm{mL})$ [25]. Os resultados mostram que, na presença de ambos os LI, a solubilidade da cafeína é maior $(22,21 \pm 0,91 \mathrm{mg} /$ $\mathrm{mL}$ com [Cho][Cys] e 24,74 $\pm 1,01 \mathrm{mg} / \mathrm{mL}$ com [Cho] [Met]), quando comparada com a sua solubilidade em água (Figura 1). Além disso, os resultados também mostram que [Cho][Met] é melhor promotor de solubilidade do que [Cho][Cys], com diferenças estatisticamente significativas $(\mathrm{p}<0,001)$.

Também é bastante relevante confirmar que, apesar de ambos os LI permitirem uma melhoria significati- 
this enhancement was less prominent than what was previously obtained by our group in the presence of other two choline-based ILs, namely [Cho][Phe] and [Cho][Glu] [16]. This difference clearly shows that the type of anion used to prepare the choline-based ionic liquid is crucial to the efficiency of these salts as solubility promotors. These differences are likely due to distinct affinities between the drug and the various anions that may constitute these IL.

Nonetheless, the present results reinforce the hypothesis that ILs may be used as functional excipients in drug delivery systems, as even at low concentrations they improve drug solubility. va na solubilidade da cafeína, este aumento foi menos proeminente do que o anteriormente obtido pelo nosso grupo na presença de outros dois LIs derivados da colina, nomeadamente [Cho][Phe] e [Cho][Glu] [16]. Essa diferença mostra claramente que o tipo de anião usado para preparar estes líquidos iónicos é crucial para a eficiência destes sais como promotores de solubilidade. Estas diferenças são provavelmente devidas a distintas afinidades entre o fármaco e os vários aniões que podem constituir estes LI.

No entanto, os presentes resultados reforçam a hipótese de que os LI podem ser utilizados como excipientes funcionais em sistemas de veiculação de fármacos, pois, mesmo a baixas concentrações, melhoram a solubilidade do fármaco.

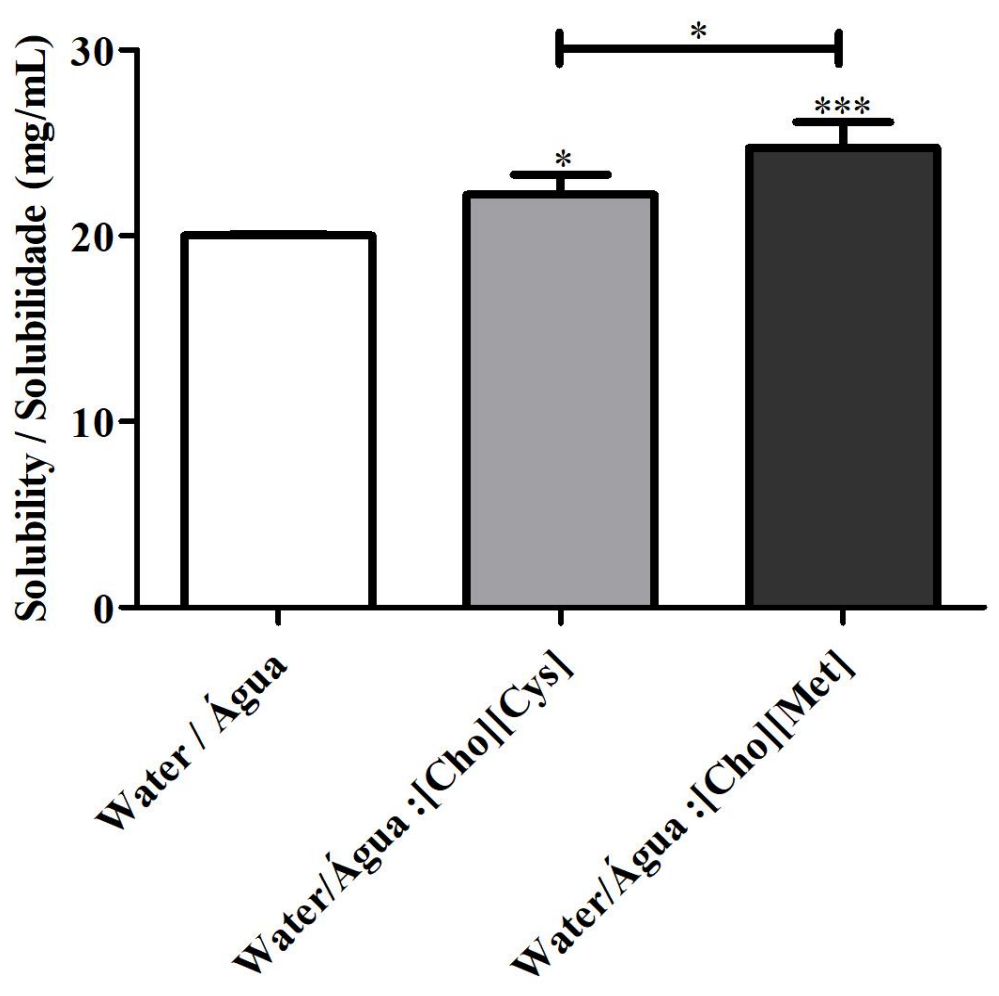

Figure 1/ Figura 1 - Caffeine solubility in water or water:IL mixtures (99.8:0.2, w/w) at $25 \pm 2$ ${ }^{0} \mathrm{C} . \mathrm{n}=3$, mean $\pm \mathrm{SD},{ }^{*} \mathrm{p}<0.05$ and $* * * \mathrm{p}<0.001$ (ANOVA, Tukey's test). Solubilidade da cafeína em água ou mistura de água:LI $(99,8: 0,2, \mathrm{~m} / \mathrm{m})$ a $25 \pm 2{ }^{\circ} \mathrm{C} . \mathrm{n}=3$, media $\pm \mathrm{DP}, * \mathrm{p}<0,05 \mathrm{e}^{* * *} \mathrm{p}<0.001$ (ANOVA, teste de Tukey). 


\section{Conclusion}

Two choline-based ILs, [Cho][Met] and [Cho][Cys], were prepared and their potential as solubility enhancers of the model active caffeine was assessed. The solubility studies were performed in water and a water:IL mixture at a ratio of 99.8:0.2, since this is the highest concentration of IL that allows the maintenance of cell viability.

Results showed that, even when present at low non-toxic concentrations, both studied ILs enhance the solubility of caffeine, when compared with the solutions in the absence of IL. Moreover, [Cho][Met] proved to be a better solubility promoter than [Cho][Cys]. Results also indicate that the type of anion used is crucial for the efficiency of these ILs as solubility enhancers. Also, in previous studies, using other choline-based ionic liquids, it was possible to reveal a higher impact in drug solubility, thus showing that different ionic liquids, even from the same class, may have a different impact as functional ingredients, particularly as solubility enhancers.

Hence, this study reinforces the potential use of various choline-based ILs as functional ingredients in drug delivery systems, and the relevance to continue evaluating the utility of these salts, without ignoring their toxicity, as they may only be considered functional excipients if this functionality is achievable at non-toxic concentrations.

\section{Acknowledgments}

This work was financed by national funds through FCT - Foundation for Science and Technology, I.P., under the project UID/DTP/04567/2016. Part of the work was also supported by FCT to CQB through project UID/ MULTI/00612/2013. Ana Júlio acknowledges his research grant attributed in the scope of the project UID/ DTP/04567/2016.

\section{Conflict of Interests}

The authors declare there are not conflict of interests.

\section{Conclusão}

Dois LI derivados de colina, [Cho][Met] e [Cho][Cys], foram preparados e o seu uso potencial como promotores da solubilidade do ativo modelo cafeína, foi avaliado. Os estudos da solubilidade foram realizados em água e em misturas de água:LI (99,8: 0,2), uma vez que esta é a concentração mais elevada de de LI que permite a manutenção da viabilidade celular.

Os resultados mostraram que, mesmo a quando presentes a concentrações baixas e não tóxicas, ambos os LI estudados aumentam a solubilidade da cafeína, quando comparados com as soluções na ausência de LI. Além disso, [Cho][Met] provou ser um melhor promotor de solubilidade do que [Cho][Cys]. Os resultados indicam claramente que o tipo de anião utilizado é crucial para a eficiência destes LI como promotores de solubilidade. Adicionalmente, em estudos anteriores usando outros líquidos iónicos à base de colina, foi possível revelar um impacto superior na solubilidade, demonstrando assim que diferentes líquidos iónicos, mesmo pertencendo à mesma classe, podem ter um impacto diferente como ingredientes funcionais, em particular como promotores da solubilidade de ativos.

Assim, este estudo reforça o potencial uso de vários LI derivados de colina em sistemas de veiculação de fármacos e a relevância de continuar a avaliar a utilidade destes sais sem ignorar a sua toxicidade, uma vez que eles apenas podem ser considerados excipientes funcionais se esta funcionalidade for atingível a concentrações não tóxicas.

\section{Agradecimentos}

Este trabalho foi suportado financeiramente pela Fundação para a Ciência e a Tecnologia (FCT, Portugal), através da bolsa UID/DTP/04567/2016 para CBIOS. Parte do trabalho foi ainda fi- nanciado pela FCT ao CQB através do projecto UID/ MULTI/00612/2013. Ana Júlio agradece a bolsa de investigação concedida no âmbito do projeto UID/ DTP/04567/2016.

\section{Conflito de Interesses}

Os autores declaram que não há relações conflito de interesses. 


\section{References/ Referências}

1. Egorova KS, Gordeev EG, Ananikov VP. Biological activity of ionic liquids and their application in pharmaceutics and medicine. Chem Rev. 2017;117(10):7132-89.

2. Ferraz R, Branco LC, Prudêncio C, Noronha JP, Petrovski Ž. Ionic liquids as active pharmaceutical ingredients. Chem Med Chem. 2011;6(6):975-85.

3. MacFarlane DR, Pringle JM, Johansson KM, Forsyth S a, Forsyth M. Lewis base ionic liquids. Chem Commun. 2006;(18):1905-17.

4. Rogers RD, Voth GA. Ionic liquids. Acc Chem Res. 2007;40(11):1077-8.

5. Sowmiah S, Srinivasadesikan V, Tseng M, Chu Y. On the chemical stabilities of ionic liquids. Molecules. 2009;14:3780-813.

6. Torimoto T, Tsuda T, Okazaki KI, Kuwabata S. New frontiers in materials science opened by ionic liquids. Adv Mater. 2010;22(11):1196-221.

7. Earle MJ, Esperança JMSS, Gilea MA, Canongia Lopes JN, Rebelo LPN, Magee JW, et al. The distillation and volatility of ionic liquids. Nature. 2006;439(7078):831-4.

8. Santos de Almeida T, Júlio A, Mota JP, Rijo P, Reis CP. An emerging integration between ionic liquids ans nanotechnology: general uses and future prospects in drug delivery. Ther Deliv. 2017;6(8):461-73.

9. Ghandi K. A review of ionic liquids, their limits and applications. Green Sustain Chem. 2014;4(February):44-53.

10. Kubota K, Shibata A, Yamaguchi T. The molecular assembly of the ionic liquid/aliphatic carboxylic acid/aliphatic amine as effective and safety transdermal permeation enhancers. Eur J Pharm Sci. 2016;86:75-83.

11. Czekanski L, Santos de Almeida T, Portugal Mota J, Rijo P, Araújo MEM. Synthesis of benzoazole ionic liquids and evaluation of their antimicrobial activity. Biomed Biopharm Res. 2014;11(2):227-35.

12. Gouveia W, Jorge TF, Martins S, Meireles M, Carolino M, Cruz C, et al. Toxicity of ionic liquids prepared from biomaterials. Chemosphere. 2014;104:516.

13. Álvarez MS, Esperança JMSS, Deive FJ, Sanromán MÁ, Rodríguez A. A biocompatible stepping stone for the removal of emerging contaminants. Sep Purif Technol. 2015;153:91-8.

14. Marrucho IM, Branco LC, Rebelo LPN. Ionic liquids in pharmaceutical applications. Annu Rev Chem Biomol Eng. 2014;5:527-46.

15. Mitkare SS, Lakhane KG, Kokulwar PU. Ionic liquids: Novel Applications in Drug Delivery. Res J Pharm Technol. 2013;6(11):1274-8.

16. Santos de Almeida T, Júlio A, Saraiva N, Fernandes AS, Araújo MEM, Baby AR, et al. Choline- versus imidazole-based ionic liquids as functional ingredients in topical delivery systems: cytotoxicity, solubility, and skin permeation studies. Drug Dev Ind Pharm. 2017;43(11):1858-65.

17. Shamshina JL, Barber PS, Rogers RD. Ionic liquids in drug delivery. Exper Opin Drug Deliv. 2013;10(10).

18. Dobler D, Schmidts T, Klingenhoefer I, Runkel F. Ionic liquids as ingredients in topical drug delivery systems. Int J Pharm. 2012;441(1-2):620-7.

19. Lawrence MJ, Rees GD. Microemulsion-based media as novel drug delivery systems. Adv Drug Deliv Rev. 2000;45(1):89-121.

20. Qiu Z, Texter J. Ionic liquids in microemulsions. Curr Opin Colloid Interface Sci. 2008;13(4):252-62.

21. Zech O, Thomaier S, Bauduin P, Rück T, Touraud D, Kunz W. Microemulsions with an ionic liquid surfactant and room temperature ionic liquids as polar pseudo-phase. J Phys Chem B. 2009;113(2):465-73.

22. Zhu W, Guo C, Yu A, Gao Y, Cao F, Zhai G. Microemulsion-based hydrogel formulation of penciclovir for topical delivery. Int J Pharm. 2009;378(12):152-8

23. Hough WL, Smiglak M, Rodríguez H, Swatloski RP, Spear SK, Daly DT, et al. The third evolution of ionic liquids: active pharmaceutical ingredients. New J Chem. 2007;31(8):1429-36.

24. Caparica R, Júlio A, Rosado C, Santos de Almeida T. Applicability of ionic liquids in topical drug delivery systems: a mini review. J Pharmacol Clin Res. 2018;4(5):555649-55.

25. Dias M, Hadgraft J, Lane ME. Influence of membrane-solvent-solute interactions on solute permeation in skin. Int J Pharm. 2007;336(1-2):108-14. 